\title{
Transversal escharotomies: a new surgical technique adjuvant in the treatment of chronic ulcers with non-arterial etiology in the lower limbs ${ }^{1}$
}

\author{
Escarotomias transversais: uma nova opção cirúrgica adjuvante no tratamento de \\ úlceras crônicas de etiologia não arterial em membros inferiores ${ }^{1}$
}

\author{
Mário Augusto Silva Freitas², Maria do Carmo Cardia Julião ${ }^{3}$ \\ 1. Post-graduate Program on Health and Development in West Central Region, Federal University of Mato Grosso do Sul (UFMS), Brazil. \\ 2. Vascular Surgeon, PhD, Associate Professor of the Department of Health and Biological Science, UFMS, Brazil. \\ 3. Anesthesiologist and Pain Management, PhD, Assistant Professor of the Department of Health and Biological Science, UFMS, Brazil.
}

\begin{abstract}
Purpose: Propose a new and alternative surgical procedure in order to aid on treatments of chronic ulcers with non-arterial etiology in the lower limbs, especially those that reoccurs and accomplish of dermatosclerosis and skin contractures determining ankle and foot limits. Methods: It describes a medical case regarding a female, 54 years old, with a pre-existing ulcer (sixteen years) on her left leg. Despite of conventional treatments such as curatives, compressive therapy and surgeries, the ulcer on her leg was not cured for three years. The skin dermatosclerosis on her foot and ankle limited her mobility tremendously. The surgery involved the debridement of the ulcers, local phlebectomies and the correction of her scar contraction by a transversal escharotomies. Conventional procedures were applied in pre and post-surgery. Results: After twelve weeks, the ulcer was completely healed by second intention. Despite the odds, she regained sustainable mobility in her foot and ankle, allowing this patient to wear medical elastic socks. Reoccurrences of the ulcer did not occur during the two years post-surgery. Conclusion: The transversal escharotomies may favor the healing of non-arterial chronic ulcers in the lower limbs, impeding perpetual mechanisms of this sort. For example, the ankle and foot limitation determinates in secondary scars, skin contractures, dermatosclerosis that produce the failure in the muscular calf-pump with deterioration in the ascending venous propulsion.
\end{abstract}

Key words: Venous ulcer. Fibrosis. Contracture. Skin section. Escharotomy.

\section{RESUMO}

Objetivo: Apresentar uma nova alternativa cirúrgica para auxiliar o tratamento de úlceras crônicas de etiologia não arterial em membros inferiores, especialmente aquelas com recidivas e complicadas por contraturas de pele, limitando movimentos do pé e tornozelo. Métodos: Descrição de caso de uma paciente portadora de úlcera em perna esquerda com dezesseis anos de evolução, múltiplas recidivas, sem cicatrização há três anos apesar de curativos convencionais, terapias compressivas e cirurgias. As contraturas cicatriciais e a dermatoesclerose local limitavam a marcha pela redução da mobilidade do pé e tornozelo. A cirurgia realizada foi o debridamento tangencial da úlcera, flebectomias locais e a correção das contraturas de pele por meio das escarotomias transversais. Após a cirurgia foram mantidos os mesmos padrões de curativos e a terapia compressiva utilizada no pré-operatório. Resultados: Houve cicatrização completa da úlcera, por segunda intenção, doze semanas após a cirurgia com ganho importante na amplitude dos movimentos do pé e tornozelo, permitindo normalização da marcha e adaptação ao uso de meias elásticas terapêuticas. Não houve recidiva em dois anos de acompanhamento pósoperatório. Conclusão: Esta técnica parece favorecer a cicatrização de úlceras crônicas de etiologia não arterial atuando em mecanismos perpetuadores do processo, como, por exemplo, a limitação da propulsão venosa pela musculatura da panturrilha determinada por contraturas cicatriciais e pela dermatoesclerose do pé e tornozelo.

Descritores: Úlcera venosa. Fibrose., Contratura. Seção de pele. Escarotomia.

\section{Introduction}

For many centuries the chronic ulcers were treated and many types of therapies proposed the healing of these ulcers, which remain a challenge for those whom have it and for the physicians whom treated as well ${ }^{1}$. A chronic venous insufficiency is the major factor in triggering the ulcers in the inferior limbs, especially after episodes of deep venous thrombosis. Refluxes related to the superficial venous system may also determine important dermatosclerosis in maleolar areas ${ }^{2}$. The degree of venous hypertension, the number of reoccurrences, the association with secondary infections, the development of lymphatic disease and the process of cicatrisation of the individual, can, isolated or jointly, determine the formation of dermatosclerosis and skin contractures around the ulcers ${ }^{\mathbf{1 6}}$. These modified areas of the skin-rigidity when located in the ankle gradually constrict the movement of the foot and, 
consequently, reduce the calf-propulsion activity, which is the most important mechanism of the physiological ascending venous return ${ }^{3}$. Longitudinal escharotomies is many times used in patients with serious burnings in order to release the constriction, preventing the development of compartmental syndromes in vulnerable areas of vascular restrain after full-size edemas such as in the upper limbs, lower limbs and in the abdomen ${ }^{4,5}$. Constantly, the surgical approach to the insufficient veins in the inferior limbs is made in free areas of the skin dermatosclerosis not only for the prevalent easiness of this technique, however, also for the suspect of these incisions done on fibroid tissues that present difficulties to cicatrisation ${ }^{6}$. The current venous surgery techniques used to favors the cicatrisation of these chronic venous ulcers consist essentially in the correction of the superficial venous reflux by means of veins ligatures from the perforate venous system or through several options of flebectomies ${ }^{7}$. The correction of the limitation the movement of the ankle, which increase the functionality of venous surgery that normally would be proposed in these cases by increasing the physiological venous return in the compromised limb. The transversal escharotomies offer a modified technique to the approach of the serious chronic venous insufficiency of the inferior limbs. This proposal combines standard techniques to correct the venous reflux with new alternative to greater motion of the ankle by the treatment of the mechanical limitations produced by the alterations of the skin in the areas surrounding the ulcers.

\section{Methods}

\section{Case description}

The patient is a female, 54 years old, presenting a chronic ulcer in left inferior limb; in the internal ankle region (Figure 1) and the chronic ulcer is approximately sixteen years old. The patient explained that her ulcers returned multiple times; the exposed wound area remained unhealed for approximately three years despite regular treatments with conventional curatives and compressive therapies. Due to her ankle dermatosclerosis and to the significant scar retractions in the dorsal foot (Figure 2), it all evolved with a medial deviation (foot-line) that determined an inadequate stride. Past clinical history has shown a controlled systemic arterial hypertension and venous surgery (internal safenectomy and flebectomies) approximately ten years ago. In the physical examination beyond the described ulcer, it was observed that the foot-plantar-flexion was totally blocked keeping only a discrete foot-reverse-flexion. In the evaluation of her stride, the halux did not touch the ground during the ramble (Figure 3) therefore; the total amplitude of her maximum-flexion-extension of the foot was 05 (five) goniometrical degrees. There are presence of varicosities and a palpable pulse in the anterior tibial artery. The posterior tibial artery was detected only to the unidirectional Doppler. The vascular echography demonstrated average residual varicosities surrounding the ulcer with local reflux. The deep venous system did not present any detectable obstructions.

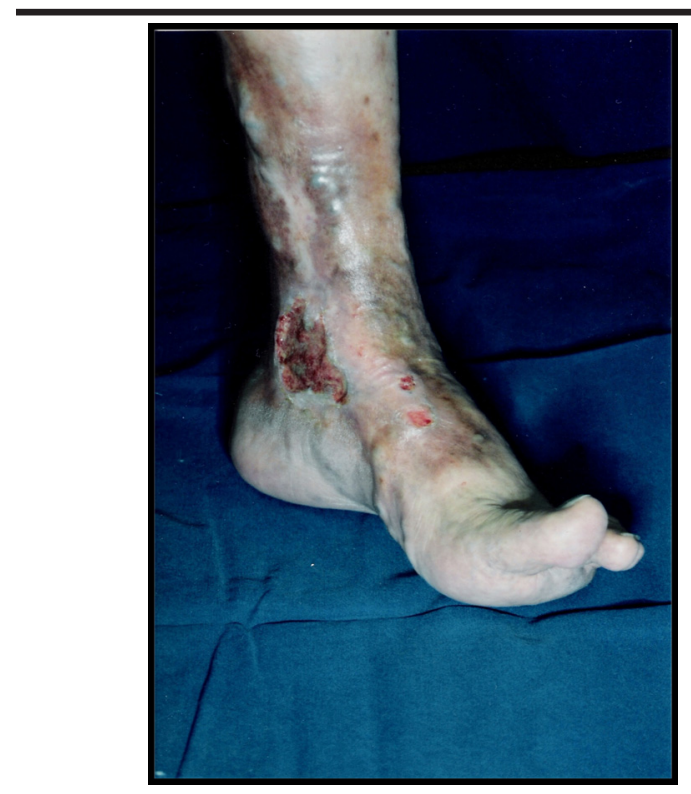

FIGURE 1 - Internal ankle ulcer. Preoperative aspect. The ulcer area surrounding by dermatosclerosis and severe scar contractures.

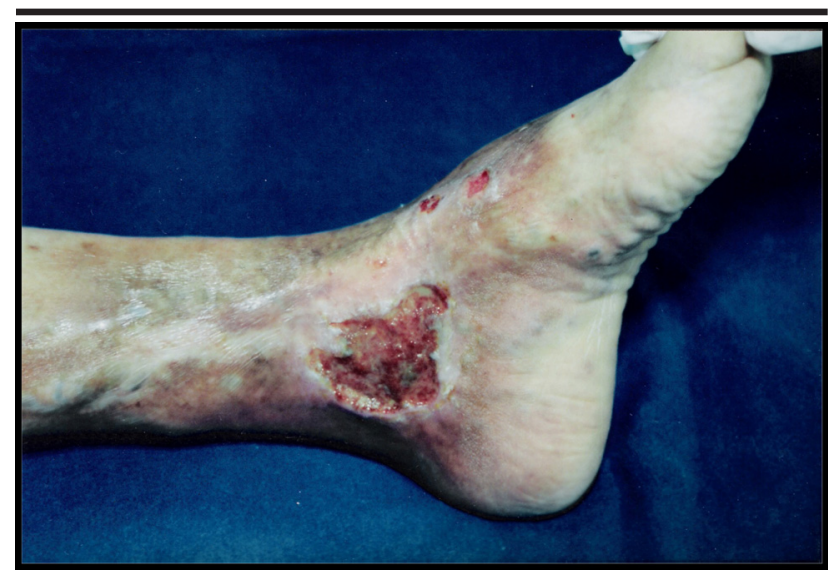

FIGURE 2 - Internal ankle ulcer. Preoperative aspect. The most important scar contracture in the maleolar and dorsal foot region are in evidence (arrows) after the forced plantar flexion of halux monitored by examiner.

FIGURE 3 - Internal ankle-ulcer. Preoperative aspect.

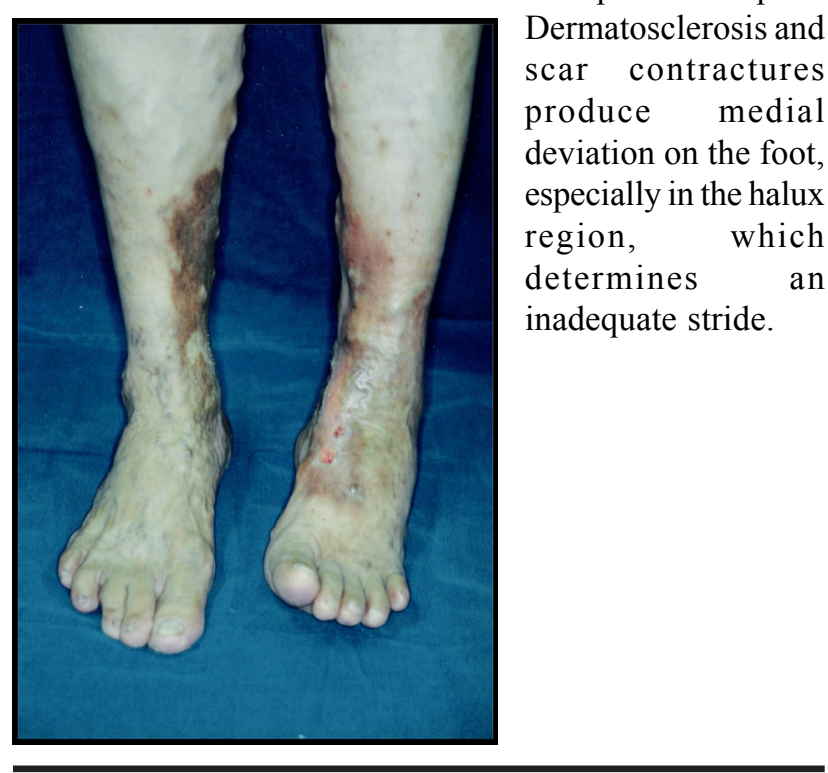




\section{Surgical technique}

The patient was positioned in a supine position after a spinal anesthesia procedure. After stabilization from anesthesia, she was positioned in a Trendelemburg position in order to reduce bleeding in surgical region. After a standard antiseptic procedure, the residual varicosities surrounding de ulcer was removed by avulsion in staggered incisions. The surgical tangential (shaving) debridement of the area of the ulcer was carried through, reaching a more vascularizated areas, allowing a discrete blood oozing surrounding the tissues. It was accomplished the forced plantar-flexion of the halux in the left foot by evidencing the areas of scar contractures. Then, the first incision made in the anterior maleolar line of the ankle (lateral to medial) was performed. Furthermore, the ligaments and the articular capsule were preserved around all thickness of the dermatosclerotic tissues. Moreover, two complementary transversal escharotomies were done in the same way, above and below the first incision (Figure 4). The deepness of the dermatosclerotic areas had been liberated by direct traction of the superficial tissues. The initial hemostasy was by means of " $X$ " sutures with a 4-0 non-absorbable monofilamentary wire (nylon or polypropylene), directly in the blood vessel of the opened areas. After, the hemostasy was complemented by local compression. The transversal escharotomies had been left opened in order for the secretions to drain and the second intention healing could occur. In the postoperative dressing it was used ointment gauzes with vaseline to prevent bleeds in the first curative done after 48 (forty and eight) hours. In the postoperative time, non-adherent curatives were done three times per week besides being kept the compress therapy with conventional bands in a similar way that they were carried through previously to the surgery. It is very important to leave a space of two or three centimeters between each incision of escharotomy, preventing ischemic skin damage that will be formed in the subcutaneous flaps (Figure 5). The incisions did not injure the tendons-cuffs. As a matter of fact, the only incision did not extend $50 \%$ of the perimeter in the maleolar ankle line where it had been done in order to preserve the lymphatic vessels in the reminiscent area.

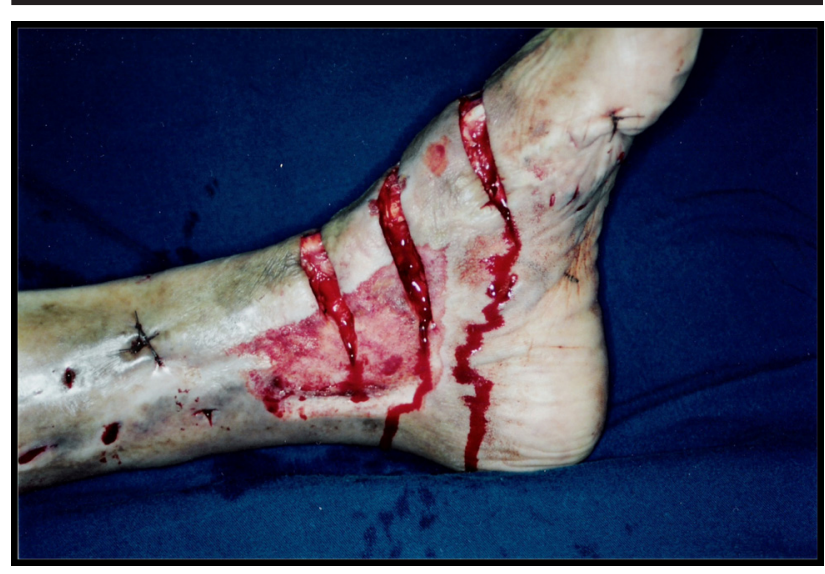

FIGURE 4 - Postoperative aspect of transversal escharotomies. Extended incision over surgical tangencial (shaving) debridement of ankle ulcer.

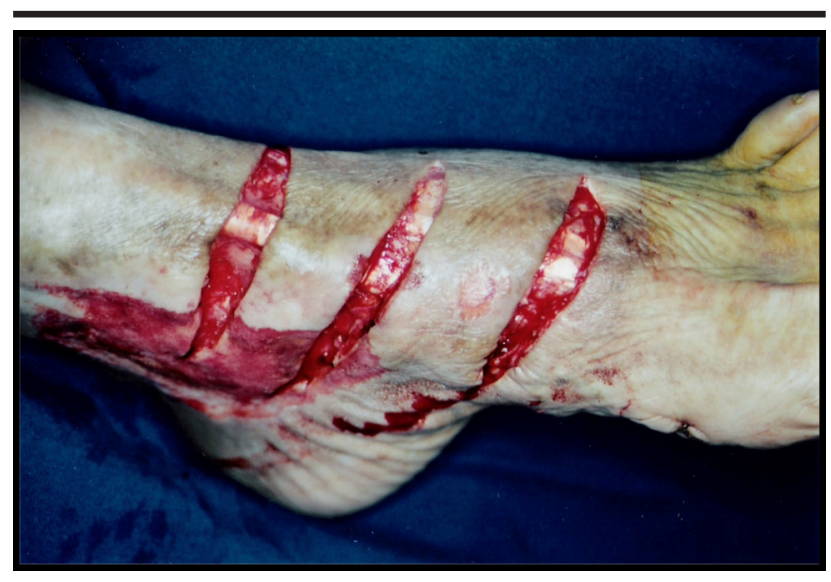

FIGURE 5 - Postoperative aspect of transversal escharotomies. Incisions liberate the scar contractures and ankle dermatosclerosis with preserving the tendonscuffs. The only incision did not extend $50 \%$ of the perimeter in the maleolar ankle line.

\section{Results}

A complete healing of the ulcer and the transversal escharotomies by second intention occurred after twelve weeks post surgery. The patient presented a vast increase in the amplitude of the movements of her foot and ankle. Moreover, an assessment was done by goniometry, which showed an increase of 05 (five) degrees in the dorsal-flexion part of the foot (Figure 6) and of 12 (twelve) degrees in the plantar-flexion of the foot (Figure 7), allowing the normalization of her stride. The maximum amplitude of flexion-extension of the foot was approximately of 05 (five) before surgery to 22 (twenty and two) degrees after the surgery, which is a considerable gain in flexion-extension goniometry. With the improvement of the edema and the recovery of the normal morphology of the ankle, it was made possible to use medical-elastic-socks and therefore its continued use. The patient did not experience any reoccurrence of the ulcer or the scar-retractions in approximately two years of postoperative care.

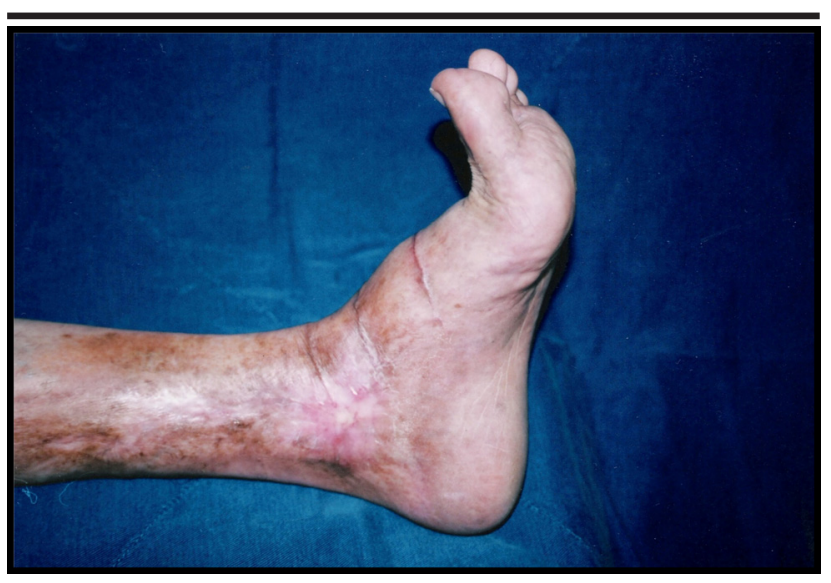

FIGURE 6 - Aspect with 12 (twelve) weeks postoperative. Ulcer and escharotomies with complete healing (second intention) with moderate gain $(+50)$ of on the foot-dorsal-flexion. 


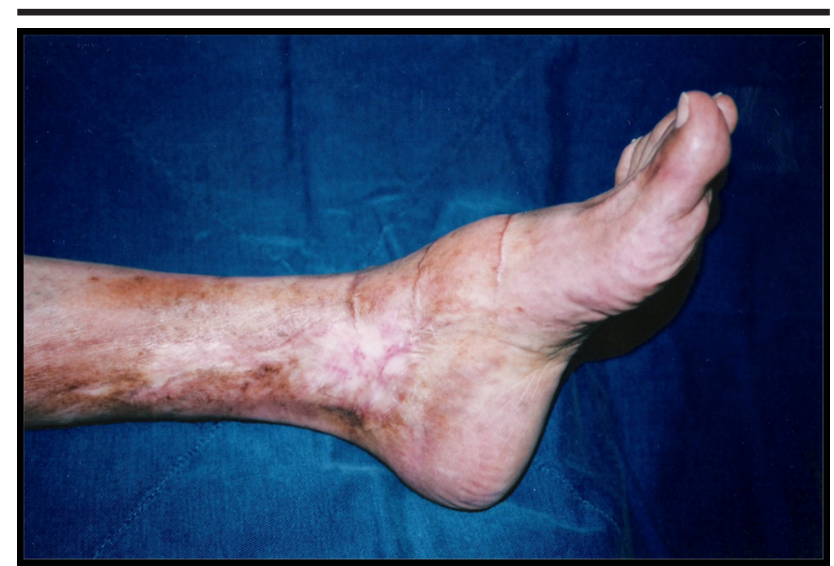

FIGURE 7-Aspect with 12 (twelve) weeks postoperative. Ulcers and escharotomies were restored to health by (second intention) with important gain $(+120)$ of on the foot-plantar-flexion.

\section{Discussion}

The general prevalence of the venous ulcers in countries of the European Community varies between 0,06 and $2 \%$, representing a raise in costs for the health system, especially for the fact of its incidence concentration roughly in the ages of 60 to the 80 years old, where the case mortality is high in surgical treatments ${ }^{\mathbf{1}, \mathbf{8}}$. In Brazil, the largest difficulty exists in characterizing the real incidence of this modality of illness, especially for the low indices of notification and the lack of integration in entering the data into the public system and private care as well. In many localities in our country, the lack of clinical reference for the treatment of the ulcers on the inferior limbs and the delay in initiating the adequate therapies determine the larger number of clinical reoccurrences. Therefore, this fact results in a large group of patients with severe dermatosclerosis and scar contractures around the ulcers limiting movements of the foot and the ankle consequently, decreased the effectiveness of the muscular pump action of the calfmuscle ${ }^{9}$. The development of the ulcers is normally associated with the high levels of venous pressures in the superficial veins. This alteration is normally secondary to valve disruptions, perforate veins reflux after obstruction on the deep vein system and muscular-calf dysfunction. Thus, in the last analysis, the overload of the venous system is due to blood reflux in the veins, to ascending blood flow obstruction and to the low capacity of proximal blood flow propulsion ${ }^{\mathbf{1 0}}$. Frequently, one high index that predicts the formation of ulcers occurs when the insufficiency of the superficial veins is combined with reflux in perforate veins, which is extended drastically when followed by some degree of obstruction or insufficiency in the deep venous system ${ }^{\mathbf{1 1}}$. The inadequate function of deep venous system can significantly make it difficult or at delay the healing of active ulcers of the inferior limbs, exactly after correction of superficial refluxes ${ }^{3}$. The physiologic venous return of deep system may be able to ameliorate by means of calf-muscle liberation". The correction of skin contractures and dermatosclerosis of the ankle could be associated to improve the mechanical blood propulsion and will produce favorable results in this fashion. Pressures raised in the venous system can be transmitted to the capillary system, causing an leakage of fibrinogen to the pericapillary space and its polymerization by forming "layers" of fibrin that difficult the tissues exchanges and the cellular oxygenation 12. This mechanism is probably the most determinant factor for a high hypoxic vulnerability in the areas of dermatosclerosis and skin contractures ${ }^{\mathbf{1 3}, \mathbf{1 4}}$. The fibroid tissues of these regions delimit areas where it is not adequate reducing the interstitial edema despite the use of standardized compressive therapies. The transversal escharotomies probably improve the draining of edema confined in these places besides and stimulating neoangiogenesis by means of transforming granulating tissues $^{16}$. Thus, it would allow these tissues to have better perfusion conditions and more oxygenation to permit the dermal epithelia can be developed in order to cover the opened areas adequately. The surgeries that correct the superficial venous reflux normally prevent the return of the ulcers, however, separately; it cannot be enough to determine the cicatrisation of chronic ulcers, particularly those of long evolution ${ }^{17}$. The reduction of the edema, the maintenance of the pumping ascending venous flow and an adequate perfusion in the capillary beds of tissues are basic conditions so that the cicatrisation of the venous etiology ulcers ${ }^{\mathbf{1 9}, 18}$. The release of epithelial growth factors (EGF) and vascular endothelial growth factors (VEGF) stimulated by acute inflammatory mediators after surgical procedures such ulcer standart or tangential debridements it be able to justify the developing tissues-granulation after the this procedures ${ }^{11}$. So, the favorable aspect and the high concentration of the tissue-granulation observed in these transversal escharotomies fields could have its origin in the same way described above. The deformities produced by the foot and ankle skin contractures may be determine difficulties in the normal walk. This deformities remains after the ulcer healing and may be not permit the use of medical elastic-socks. These facts permit a larger risk of reoccurrences ${ }^{7}$. The normalization of the ankle morphology and motion allows greater adaptation and better adherence to postoperative compressive therapy ${ }^{15}$.

\section{Conclusion}

The transversal escharotomies may favor the healing of non-arterial chronic ulcers in the lower limbs, impeding perpetual mechanisms of this sort. For example, the ankle and foot limitation determinates in secondary scars, skin contractures, dermatosclerosis that produce the failure in the muscular calf-pump with deterioration in the ascending venous propulsion. 


\section{References}

1. Rucley CV. Socioeconomic impact of chronic venous insufficiency and leg ulcers. Angiology. 1997;14(4):57-64.

2. Margolis DJ, Berlin JA, Strom BL. Risk factors associated with the failure of a venous leg ulcer to heal. Arch Dermatol. 1999;135(8):920-6.

3. Christopoulos D, Nicolaides AN, Cook A, Irvine A, Galloway JM, Wilkinson A. Pathogenesis of venous ulceration in relation to the calf muscle pump function. Surgery. 1989;106(5):829-35.

4. Wong L, Spence RJ. Escharotomy and fasciotomy of the burned upper extremity. Hand Clin. 2000;16(2):165-74.

5. Burd A, Noronha FV, Ahmed K, Chan JY, Ayyappan T, Ying SY, Pang P. Descompression not escharotomy in acute burns. Burns. 2006;32(3):84-92.

6. Stadelmann WK, Digenis AG, Tobin GR. Impediments to wound healing. Am J Surg. 1998;176(2):39-47.

7. Fletcher A, Cullum N, Sheldon TA. A systematic review of compression treatment for venous leg ulcers. Br Med J. 1997;315(7108):576-80.

8. Nelsen O, Bergqvist D, Lindhagen A. Venous and nonvenous leg ulcers: clinical history and appearance in a population study. Br J Surg. 1994;81(2):182-7.

9. Orsted HL, Radke L, Gorst R. The impact of musculoskeletal changes on the dynamics of the calf muscle pump.Ostomy Wound Manage. 2001;47(10):18-24.

10. Christopoulos D, Nicolaides NA, Szendro G. Venous reflux: quantification and correlation with the clinical severity of chronic venous disease. Br J Surg. 1988;75(4):352-6.

11. Theopold C, Yao F, Eriksson E. Gene therapy in the treatment of lower extremity wounds. Low Extrem Wound. 2004;3(2):69-79.

12. Burnand KG, Whismter I, Naidoo A, et al. Pericapillary fibrin in the ulcer-bearing skin of the leg: the cause of lipodermatosclerosis and venous ulceration. Br Med J. 1982; 285(6348):1071-2.
13. Mulder G, Jones R, Cederholm-Williams S, et al. Fibrin cuff lysis in chronic venous ulcers trest with hydrocolloid dressing. Int J Dermatol. 1993;32(4)304-6.

14. Stacey MC, Burnand KG, Bhogal BS, Black MM. Pericapillary fibrin deposits and skin hypoxia precede the changes of lipodermatosclerosis in limbs at increased risk of developing a venous ulcer. Cardiovasc Surg. 2000;8(5):372-80.

15. Partsch H. Compression therapy of legs. A review. J Dermatol Surg Oncol. 1991;17(10):799-805.

16. Vranckx JJ, Slama J, Preuss S, et al. Wet wound healing. Plast Reconstr Surg. 2002;110(7):1680-7.

17. Steed DL, Donohoe D, Webster NW, et al. Effect of extensive debridement and treatment on the healing of diabetic foot ulcers. Diabetic Ulcers Study Group. J Am Coll Surg. 1996;183(1):61-4.

18. Yager DR, Zhang LY, Liang HX, et al. Wound fluids from human pressure ulcers contain elevated matrix metalloproteinase levels and activity compared to surgical wound fluids. J Invest Dermatol. 1996;107(5):743-8.

19. Bechara FG, Sand M, Sand D, Stucker M, Altmeyer P, Hoffmann K. Shave therapy for chronic venous ulcers: a guideline for surgical management and postoperative wound care. Plast Surg Nurs. 2006;26(1):29-34

20. Trent JT, Falabella A, Eaglstein WH, Kirsner RS. Venous ulcers: pathophysiology and treatment options. Ostomy Wound Manage . 2005;51(5):38-54.

\section{Acknowledgements}

Osíris Ramacciotti, MD and Luismar dos Santos, MD Vascular Surgeons Specialists of "Dr. Christóvão da Gama" Hospital, Santo André, SP, for opportunity in the conduction of Ulcers Ambulatory in this institution. Marilene BarrosLuis, MA - PhD Student and Lecturer at the University of California Santa Barbara, for English revision.

\section{Correspondence:}

Mário Augusto da Silva Freitas

Rua Bruno Garcia, 684 / 201

79.601-060 - Centro - Três Lagoas - MS - Brasil

e-mail: maugus@terra.com.br
Conflict of de interest: none Financial source: none

\section{How to cite this article:}

Freitas MAS, Julião MCC. Transversal escharotomies: a new surgical technique adjuvant in the treatment of chronic ulcers with non-arterial etiology in the lower limbs. Acta Cir Bras. [serial on the Internet] $2006 ; 21$ Suppl 4. Available from URL: http://www.scielo.br/acb. 